\title{
Effect of condition index on allometric relationships of clearance rate in Mytilus galloprovincialis Lamarck, 1819
}

\author{
Efecto del índice de condición en las relaciones alométricas de la tasa de aclaramiento \\ en Mytilus galloprovincialis Lamarck, 1819 \\ Ramón Filgueira ${ }^{1}$, Uxío Labarta ${ }^{1}$ and María José Fernández-Reiriz ${ }^{1}$ \\ ${ }^{1}$ Consejo Superior de Investigaciones Científicas (CSIC), Instituto de Investigaciones Marinas \\ C/Eduardo Cabello 6, 36208 Vigo, Spain \\ mjreiriz@iim.csic.es
}

\begin{abstract}
Resumen.- Las relaciones alométricas de la tasa de aclaramiento (TA) con la talla y TA con el peso muestran una considerable variabilidad en la literatura científica. Sin embargo, estas alometrías han sido empleadas de forma habitual como referencia para evaluar y criticar metodologías de trabajo y resultados experimentales. Se diseñaron dos experimentos para evaluar la incidencia del índice de condición sobre dichas relaciones alométricas en Mytilus galloprovincialis. Los resultados revelan un efecto significativo de este índice sobre la relación alométrica en la que el peso es la variable dependiente, lo cual limita el uso de dicha alometría a las condiciones particulares de cada experimento.

Palabras clave: Exponente alométrico, constante de normalización, área branquial, bivalvo
\end{abstract}

\section{Introduction}

Physiological processes and morphological structures in bivalves are related to the size of the individual. The scaling of the biological variables with increasing size can be described by power functions of the form:

$$
\mathrm{Y}=\mathrm{Y}_{0} \mathrm{M}^{\mathrm{b}}
$$

where $\mathrm{Y}$ is the biological variable, $\mathrm{Y}_{0}$ the normalization constant, $\mathrm{M}$ the body mass, and $\mathrm{b}$ the allometric scaling exponent. One of the most important points of controversy in scientific discussion about power functions is focussed on the value of the exponent. In fact, there is ongoing discussion in the scientific literature concerning the exponent of the metabolic relationship allometry (West et al. 1997, 1999, Dodds et al. 2001, White \& Seymour 2003), the best known allometric relationship. On the other hand, several recent studies provided evidences that support certain variability in the exponent of allometric scaling laws (i.e. Riisgård 1998, Atanasov \& Dimitrov 2002, Bokma 2004, Muller-Landau et al. 2006, Reich et al. 2006, White et al. 2006).

In the case of the clearance rate of bivalve molluscs, the discussion about the allometric relationships is subjected to the conceptual understanding of the bivalve

\begin{abstract}
The allometric relationships between clearance rate (CR) and length and CR and weight show considerable variability in the literature. Nonetheless, they have been used routinely as references to evaluate and criticize methodologies and experimental results. Two experiments were designed to test the incidence of the condition index on these allometric relationships in Mytilus galloprovincialis. The results reveal a significant effect of this index on the allometric relationship in which weight was the dependent variable, which limits the use of this allometry to the particular conditions of each experiment.
\end{abstract}

Key words: Allometric scaling exponent, normalization constant, gill area, bivalve

filtration process. On one hand, filtration has been considered to be subjected to physiological regulation (Hawkins et al. 1996, Bayne 1998) with the purpose of maximizing energy uptake (Bayne et al. 1993). Alternatively, filtration may be understood essentially as an 'automatized' process (Jørgensen et al. 1988, 1996), whereby under optimal conditions the filtration system is designed to function at maximum capacity (Riisgård 2001a). Under the conceptual understanding of an 'automatized' filtration activity, the clearance rate allometries published by Møhlenberg \& Riisgård (1979) and Riisgård (1988) have been considered as a reference to evaluate and criticize other experimental results. In this way, potential methodological pitfalls and flaws have been attributed to studies reporting a clearance rate lower than the values observed on these allometries (see review in Riisgård 2001a, 2001b). However, there is not an experimental background that permits to apply the results of Møhlenberg \& Riisgård (1979) and Riisgård (1988) to the particular conditions of different studies. In fact, several studies are clearly in conflict with the use of these allometries as a reference to evaluate other studies. Based on an extensive literature review, Powell et al. (1992) observed that the clearance rates of different-sized bivalves apparently tended to fall on one of two different 
Table 1

Normalization constant (a) and allometric scaling exponent (b) for the fit between clearance rate ( $\left(\mathrm{h}^{-1}\right)$ and length $(\mathrm{mm})$ or weight $(\mathrm{g})$ in the genus Mytilus

Constante de normalización (a) y exponente alométrico (b) para el ajuste tasa de aclaramiento ( $\mathrm{L} \mathrm{h}^{-1}$ ) con la talla (mm) o peso (g) en el género Mytilus

\begin{tabular}{cccccc}
\hline \multirow{2}{*}{ Length } & \multicolumn{2}{c}{ Weight } & Species & Study \\
a & $\mathrm{b}$ & $\mathrm{a}$ & $\mathrm{b}$ & M. edulis & Vahl 1973 \\
& & 3.90 & 0.60 & M. edulis & Riisgård \& Møhlenberg 1979 \\
& & 7.37 & 0.72 & M. edulis & Møhlenberg \& Riisgård 1979 \\
& & $7.45 \pm 1.13$ & $0.66 \pm 0.04$ & M. edulis & Bayne \& Newell 1983 \\
0.0035 & & -- & $0.607 \pm 0.13$ & M. californianus & Meyhöfer 1985 \\
0.0039 & 1.72 & 5.80 & 0.60 & M. galloprovincialis & Present survey-Experiment A \\
$0.001-0.003$ & $1.57-1.85$ & $0.99-1.38$ & $0.47-0.61$ & M. galloprovincialis & Pérez-Camacho \& González 1984 \\
0.0002 & $2.19 \pm 0.04$ & 1.78 & $0.70 \pm 0.01$ & M. edulis & Jones et al. 1992 \\
0.0012 & 2.14 & & & M. edulis & Kiørboe \& Møhlenberg 1981 \\
\hline
\end{tabular}

CR and length curves, one of which predicted CR about three times higher than the other. The strong differences between both curves for the same specie illustrate high variability in the CR allometries. In addition, several experiments have shown high variability in the exponent of the CR and length relationship, from 1.57 to 2.19, and CR and weight, from 0.47 to 0.72 , in the genus Mytilus (Table 1).

The variability in the parameters of the CR allometric relationship has been attributed to endogenous and exogenous factors. For instance, the variability observed in the normalization constant has been explained as a differential response to environmental conditions (Winter 1976, Bernard 1983) or as consequence of the condition index (Bernard 1983). On the other hand, although the allometric scaling exponent has been considered constant (Winter 1976, Bernard 1983, Jones et al. 1992), there is some evidence of variability due to both endogenous and exogenous factors. Accordingly, Pérez-Camacho \& González (1984) reported that water temperature can affect the exponent value. Pérez-Camacho \& González (1984) and Bayne et al. (1976) observed a decrease in the exponent with increasing size range of the experimental mussels. Finally, Bayne et al. (1976) suggested that the decrease in the exponent of the CR allometric relationship was related with the gill area.

The main premise that allows us to compare the results between different studies requires homogeneity in experimental conditions, which avoid the influence of significant factors on the measure of the dependent variable. Despite this premise, the allometric relationships observed by Møhlenberg \& Riisgård (1979) and Riisgård (1988) have been usually considered as a reference to evaluate and criticize other experimental results, as it was said previously. However, given the influence that both, exogenous and endogenous factors can exert on the allometric relationships in which the CR is involved, the use of these equations as references seem to be not plausible. In this way, the present paper is focussed on the study of the effect that the endogenous factor condition index may exert on the allometric relationships clearance rate (CR) and length and CR and weight.

\section{Material and methods}

The mussels, Mytilus galloprovincialis (Lamarck, 1819), were collected from a cultivation raft (Ría de Arousa, NW Spain). In the laboratory, individuals of 25-85 mm were acclimatized following the methodology described by Filgueira et al. (2006). The same acclimatization diet was used during the experiments, but the water was filtered through $0.5 \mu \mathrm{m}$ in order to improve the Coulter measurements.

Total particulate matter (TPM) and particulate organic matter (POM) concentration in the diet were determined gravimetrically (in triplicate) following the methodology described by Filgueira et al. (2006). Chlorophyll was extracted using acetone (90\%) and quantified by means of the equation of Jeffrey \& Welschmeye (1997) for algae of the Chromophyte division. The characteristics of the diet are shown in Table 2. 
Table 2

\begin{abstract}
Characteristics of the diets used in the two experiments (mean and standard deviation): total particulate material (TPM, mg L $\mathbf{L}^{-1}$ ), particulate organic material (POM, mg L $\left.{ }^{-1}\right)$, quality (f = POM / TPM), chlorophyll (Chla, $\left.\mu \mathrm{g} \mathrm{L}^{-1}\right)$, particulate density (Part. Den., number of particulates $\mathrm{mL}^{-1}$ ) and particulate volume (Part. Vol., $\mathrm{mm}^{3} \mathrm{~L}^{-1}$ ). The results of the t-tests (t, d.f. and $P$ ) for both experiments are also shown
\end{abstract}

Características de las dietas empleadas en los dos experimentos (media y desviación estándar): material particulado total (TPM, mg L ${ }^{-1}$ ), material orgánico particulado (POM, mg L-1), calidad ( $\left.\mathrm{f}=\mathrm{POM} / \mathrm{TPM}\right)$, clorofila $\left(\mathrm{Chla}, \mu \mathrm{g} \mathrm{L}^{-1}\right)$, densidad de partículas (Part. Den., número de partículas $\mathrm{mL}^{-1}$ ) y volumen particulado (Part. Vol., $\mathrm{mm}^{3} \mathrm{~L}^{-1}$ ). Se muestran los resultados de las pruebas $t$ (t, d.f. y $P$ ) para ambos experimentos

\begin{tabular}{cccccc}
\hline & Experiment A & Experiment B & $\mathrm{t}$ & d.f. & $P$ \\
\hline TPM $\left(\mathrm{mg} \mathrm{L}^{-1}\right)$ & $1.3 \pm 0.13$ & $1.4 \pm 0.09$ & 1.445 & 10 & 0.179 \\
POM $\left(\mathrm{mg} \mathrm{L}^{-1}\right)$ & $0.6 \pm 0.06$ & $0.7 \pm 0.01$ & 3.541 & 10 & $<0.05$ \\
f & $0.5 \pm 0.03$ & $0.5 \pm 0.02$ & 0.453 & 10 & 0.661 \\
Chla $\left(\mu \mathrm{g} \mathrm{L}^{-1}\right)$ & $9.7 \pm 0.56$ & $7.7 \pm 0.25$ & 8.266 & 10 & $<0.001$ \\
Part. Den. $\left(\mathrm{part} \mathrm{mL}^{-1}\right)$ & $23330 \pm 1301$ & $23093 \pm 960$ & 0.820 & 56.92 & 0.416 \\
Part. Vol. $\left(\mathrm{mm}^{3} \mathrm{~L}^{-1}\right)$ & $1.14 \pm 0.167$ & $1.10 \pm 0.092$ & 1.136 & 48.75 & 0.261 \\
\hline
\end{tabular}

The clearance rate (CR, volume of water completely cleared of particulates per unit of time) was estimated with the flow-through chamber method following the methodology described by Filgueira et al. (2006).

The gill area was measured using digital photography. Firstly, one of the mussel valves was removed, as well as the edge of the mantle, which could interfere in the photography of the outer demibranch. The mussel was placed so that the demibranch was parallel to the camera lens, and alongside a ruler to calibrate the image (Nikon $\mathrm{D} 1 \mathrm{x})$. The demibranch area was determined with computer software (analySIS 3.2, Soft Imaging System $\mathrm{GmbH})$. The gill area was then estimated by multiplying the demibranch area obtained by 8 ( 4 demibranches with 2 lamellae each).

The experimental design to test the hypothesis of the study required two populations of the same area with different condition index. Several preliminary samplings of the condition index were carried out in the field until two populations with different condition index were found. Two experiments were carried out: Experiment A (17 February 2004; 59 individuals: $27-85 \mathrm{~mm}$ ) and Experiment B (3 March 2004; 93 individuals: 24-86 mm) of $3 \mathrm{~h}$ duration. After the second and third hour, samples were taken for CR measurement and diet parameters. After the $\mathrm{CR}$ measurement, the length was determined by a Mitutoyo ${ }^{\circledR}$ calliper and the outer demibranch was photographed and the tissues were dissected to determine the dry weight $\left(110^{\circ} \mathrm{C}, 48 \mathrm{~h}\right)$ and the Freeman condition index (CI=tissue dry weight / shell dry weight $\mathrm{x} 100$, Freeman 1974).

The statistical analyses were performed using
Statistical Package SPSS 11.5. Analysis of covariance (ANCOVA, Zar 1984) was used to make comparisons between the allometric curves of both experiments using their log-transformed equations. The dietary characteristics were compared by t-tests. Where homogeneity of variance was rejected (Levene's test), a t-test for non-homogeneous variance was carried out (Snedecor \& Cochran 1989).

\section{Results}

\section{Condition index and length relationship}

$$
\begin{gathered}
\text { Exp A: CI= 8.12+0.01xLength }\left(n=59, \mathrm{r}^{2}=0.03,\right. \\
\mathrm{F}=1.523, P=0.222) \\
\text { Exp B: CI= 4.86+0.18xLength }\left(n=93, \mathrm{r}^{2}=0.65,\right. \\
\mathrm{F}=172.3, P<0.001)
\end{gathered}
$$

The condition index remained constant for the range of mussel lengths in Experiment A whereas in Experiment $B$ there was a significant linear increment of the condition index with length (Fig. 1).

\section{Gill area and dry weight relationship}

Exp A: Gill area $=5.63 \times 10^{3} \times$ Weight $^{0.66}\left(n=56, \mathrm{r}^{2}=0.94\right.$, $\mathrm{F}=866.8 \quad P<0.001$ )

Exp B: Gill area $=4.45 \times 10^{3} \times$ Weight ${ }^{0.56}\left(n=93, \mathrm{r}^{2}=0.97\right.$, $\mathrm{F}=2661, P<0.001$ )

Allometric scaling exponent (ASE): $\mathrm{t}=4.35$, d.f. $=145$, $P<0.001$

ANCOVA showed statistically significant differences between the exponents (Fig. 2A), which highlights a different relationship for each experiment. 


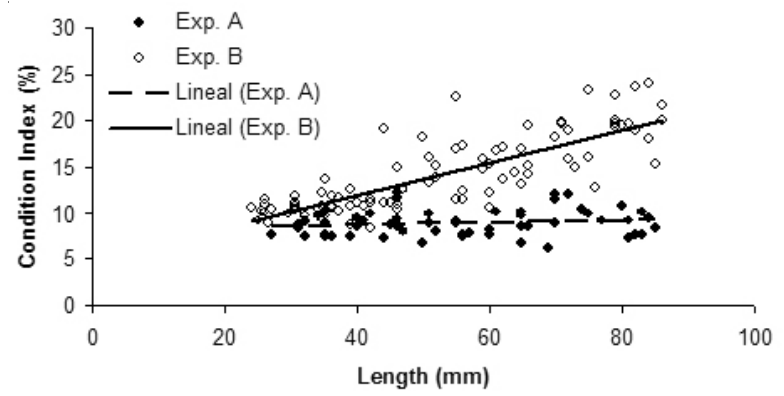

Figure 1

Freeman condition index (\%) and length ( $\mathrm{mm})$ relationship for both experiments

Relación del índice de condición de Freeman (\%) con la talla (mm) para ambos experimentos

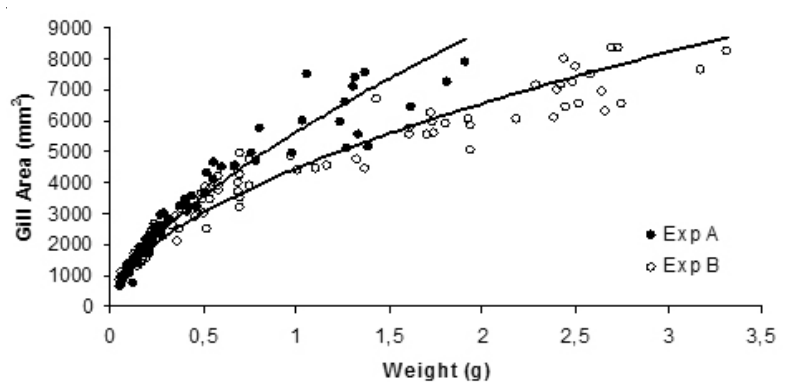

Figure 2

Gill area $\left(\mathrm{mm}^{2}\right)$ and weight $(\mathrm{g})$ relationship for both experiments

Relación del área branquial $\left(\mathrm{mm}^{2}\right)$ con el peso (g) para ambos experimentos

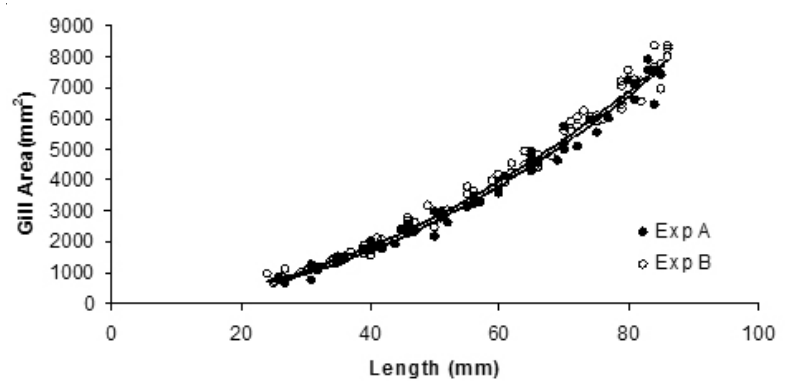

Figure 3

Gill Area $\left(\mathrm{mm}^{2}\right)$ and length $(\mathrm{mm})$ relationship for both experiments

Relación del área branquial $\left(\mathrm{mm}^{2}\right)$ con la talla (mm) para ambos experimentos

\section{Gill area and length relationship}

Exp A: Gill area $=1.18 \times$ Length $^{1.97}\left(n=56, \mathrm{r}^{2}=0.98\right.$, $\mathrm{F}=2402 P<0.001)$

Exp B: Gill area $=1.61 \times$ Length $^{1.91}\left(n=93, \mathrm{r}^{2}=0.99\right.$, $\mathrm{F}=8468, P<0.001)$

ASE: $\mathrm{t}=1.31$, d.f. $=145, P=0.192$, common ASE $=1.93$

Normalization constant (NC): $\mathrm{t}=1.78$, d.f. $=146, P=$ 0.077 , common $\mathrm{NC}=1.48$

ANCOVA showed a common fit between both experiments, which imply that the potential relationship between gill area and length remains constant and independent of the condition index (Fig. 3).

\section{Clearance rate and weight relationship}

Exp A: CR= 5.80 x Weight $^{0.60}\left(n=59, \mathrm{r}^{2}=0.86, \mathrm{~F}=352.8\right.$, $P<0.001)$

Exp B: CR= 5.02 x Weight ${ }^{0.50}\left(n=93, \mathrm{r}^{2}=0.89, \mathrm{~F}=719.7\right.$, $P<0.001)$

ASE: $\mathrm{t}=2.55$, d.f. $=148, P<0.05$

Similar to the gill area vs weight relationship, ANCOVA revealed statistically significant differences between the exponents (Fig. 4).

\section{Clearance rate and length relationship}

Exp A: CR $=3.53 \times 10^{-3} \times$ Length $^{1.72}\left(n=59, \mathrm{r}^{2}=0.85\right.$, $\mathrm{F}=316.6, P<0.001)$

Exp B: CR $=3.92 \times 10^{-3} \times$ Length ${ }^{1.72}\left(n=93, \mathrm{r}^{2}=0.91\right.$, $\mathrm{F}=967.2, P<0.001)$

ASE: $\mathrm{t}=0.01$, d.f. $=148, P=0.992$, common ASE $=1.72$

$$
\text { NC: } \mathrm{t}=2.22 \text {, d.f. }=149, P<0.05
$$

The fits did not present statistically significant differences between the exponents although differences between the constants were observed. This shows that the potential $\mathrm{CR}$ and length relationship presents the same scaling in both experiments (Fig. 5).

\section{Clearance rate and gill area relationship}

Exp A: CR $=0.38+0.97 \times 10^{-3} \times$ Gill area $(n=56$, $\mathrm{r}^{2}=0.86, \mathrm{~F}=333.9, P<0.001$ )

Exp B: CR $=0.58+0.98 \times 10^{-3} \times$ Gill area $(n=93$, $\left.\mathrm{r}^{2}=0.90, \mathrm{~F}=786.0, P<0.001\right)$

b: $\mathrm{t}=0.08$, d.f. $=145, P=0.936$, common $\mathrm{b}=0.001$

a: $\mathrm{t}=1.95$, d.f. $=146, P=0.053$, common $\mathrm{a}=0.49$

ANCOVA showed a common linear fit for both experiments. The CR thus depends directly on gill area. 


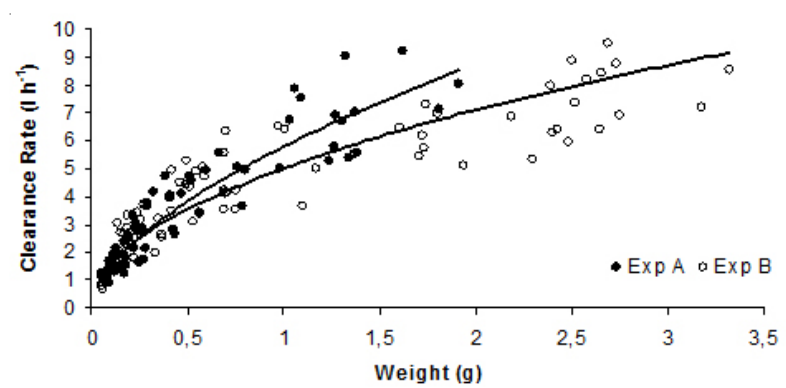

Figure 4

\section{Clearance rate $\left(\mathrm{L} \mathrm{h}^{-1}\right)$ and weight (g) relationship for both experiments}

Relación de la tasa de aclaramiento $\left(\mathrm{L} \mathrm{h}^{-1}\right)$ con el peso (g) para ambos experimentos

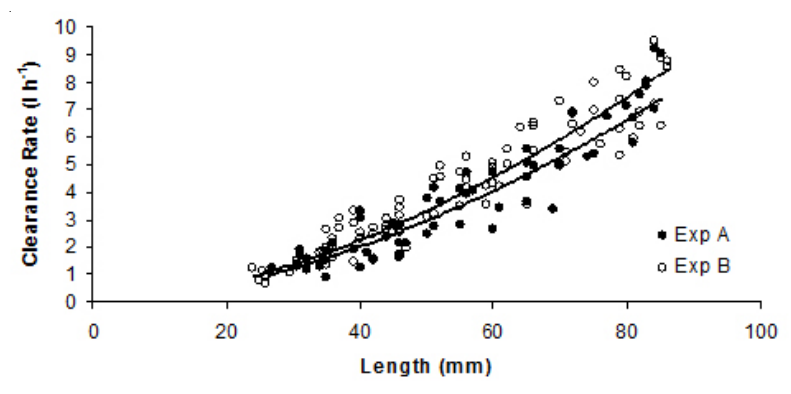

Figure 5

\section{Clearance rate $\left(\mathrm{L} \mathrm{h}^{-1}\right)$ and length $(\mathrm{mm})$ relationship for both experiments}

Relación de la tasa de aclaramiento $\left(\mathrm{L} \mathrm{h}^{-1}\right)$ con la talla $(\mathrm{mm})$ para ambos experimentos

\section{Discussion}

The comparison of clearance rate allometries published by Møhlenberg \& Riisgård (1979) and Riisgård (1988) with experimental results has been used to evaluate potential methodological pitfalls and flaws (see review in Riisgård 2001a,b). However, there is no experimental background that permits to apply these allometries as a reference to evaluate other studies. In this way, the review of Powell et al. (1992) showed strong differences in the clearance rate allometries for the same specie. Besides, different studies observed a significant effect of the environmental conditions (Winter 1976, Bernard 1983), condition index (Bernard 1983), water temperature (Pérez-Camacho \& González 1984) or size range (Bayne et al. 1976, Pérez-Camacho \& González 1984) on the parameters of the clearance rate allometric relationships.

The results of the present study show that the endogenous factor condition index does not exert a significant effect on the CR and length relationship, since the allometric scaling exponent is common for both experiments (1.72) despite the significant increase of the condition index with size observed in Experiment B. This result is confirmed by the common fit in the gill area and length relationship. Attending to the normalization constant, residual differences have been observed between experiments $\left(3.52 \times 10^{-3}\right.$ and $\left.3.93 \times 10^{-3} ; P=0.03\right)$, which may be attributed to environmental aspects in terms of availability of energy, nutrients or other essential resources of both experiments (Winter 1976, Bernard 1983, Brown et al. 2002, Hochachka et al. 2003).

With regard to the CR and weight relationship, a significant effect of the endogenous factor condition index can be observed on its exponent, as demonstrates the lack of a common exponent between experiments. These results contradict those observed by Winter (1976) who stated that the exponent of the fit CR and weight ought to be constant and independent of the CI of the individuals. Similarly, Bernard (1983) suggested that the exponent is an index of function closely tied to hydraulics of ventilation and therefore the effect of the gametogenic cycle should be reflected exclusively on the constant. The results observed in the $\mathrm{CR}$ and weight relationship are confirmed by the gill area and weight relationship, which shows the same difference in the exponents between experiments. These results differ from those reported by Jones et al. (1992), who stated that the exponent should scale according to predictions, although the intercept might vary widely. The difference in the allometric parameters between experiments could be caused by the condition index, which does not affect the gill area (Sprung 1995), meanwhile maintains a close relationship with the weight (Morton 1983). Therefore, a change in condition index implies a direct change in the gill area and weight relationship and subsequently in the CR and weight relationship. Given the significant effect of the condition index on the CR and weight relationship, the length standadization of the clearance rate seems more appropiate than weight standarization for comparative purposes, as had been suggested by Iglesias et al. (1996) and Labarta et al. (1997).

Attending to the values of parameters, the common exponent of the CR and length relationship (1.72) is within the range observed by Pérez-Camacho \& González (1984) for M. galloprovincialis (1.57-1.85), but differs from other species of the genus Mytilus (Table 1). This exponent differs from that observed in the gill area and length relationship (1.93) in spite of the direct relationship between gill area and CR. This may be due to gill structure, which co-vary with animal body length (Jones et al. 1992) and could exert a significant effect on CR. With regard to 
the normalization constant, the results show a similar pattern, the values are within the range observed for this specie (Table 1), and they are a bit higher than the observed in other species of the genus Mytilus (Table 1). Attending to the $\mathrm{CR}$ and weight relationship, the exponent and normalization constant values observed in both experiments are within the range observed for Mytilus genus (Table 1). According to the results of the present work, the differences in the exponent and constant between different studies (Table 1) could be related with differences in the condition index of the experimental individuals. Besides, the inter-specific differences could not be avoided in an inter-study comparison, as well as the experimental conditions, which could affect to the allometric parameters (Winter 1976, Bernard 1983, Brown et al. 2002, Hochachka et al. 2003). Therefore, to compare the results of different studies it is necessary to take into account the length and the weight, as well as the condition index of the experimental individuals and the experimental conditions.

In summary, the results of the present study show a significant effect of the condition index on the Allometric Scaling Exponent of the CR and weight relationship. However, our experimental design does not resolve some uncertainty regarding the effect of the condition index on the $\mathrm{CR}$ and weight relationship. For example, because of the significant differences in the exponent, the design cannot allow us to study the possible effect of the condition index on the normalization constant. Additionally, it cannot be established whether the exponent would be similarly affected if the condition index was different but constant within the size ranges. To answer these questions, three simulations were carried out based on the established in the present study: (1) changes in condition index do not affect the gill area, as observed in the common fit between gill area and length, and (2) changes in the condition index do not affect the efficiency of the filtration system, as observed in the common fit between CR and gill area. The simulations are based on a theoretical mussel population with a constant condition index (10\%) and a CR and weight relationship with an exponent of 0.66 (a theoretical value when isometry is assumed) and a constant of 5.5 (average of the present results). Once a steady-state population is established, the weight was changed to adjust the condition index according to the following:

- Population with constant and low (10\%) condition index.

- Population with constant and high (30\%) condition index.

- Population with variable condition index following the linear equation: $\mathrm{CI}=10 \mathrm{xDW}+10$ (Increment of $1 \%$ per $0.1 \mathrm{~g})$.

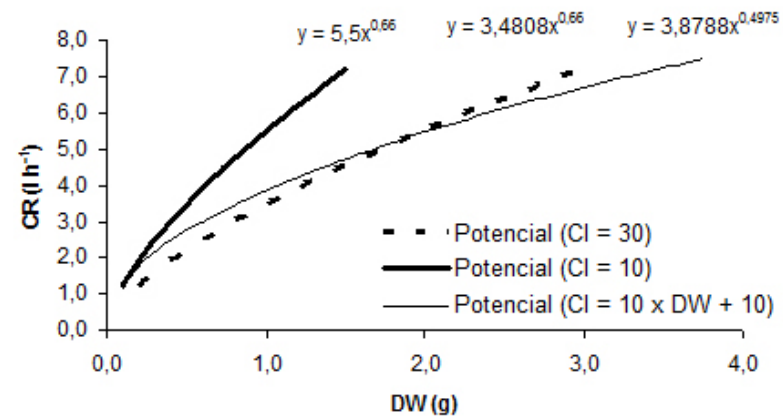

Figure 6

Simulation of clearance rate (CR) and dry weight (DW, g) relationship for a population with constant and high condition index ( $\mathrm{CI}=30$ ), constant and low condition index $(\mathrm{CI}=10)$ and with significant increase with size $(\mathrm{CI}=10 \mathrm{xDW}+10)$

Simulación de la relación de la tasa de aclaramiento (CR) con el peso seco $(\mathrm{DW}, \mathrm{g})$ para una población con índice de condición constante (CI=30), índice de condición constante y bajo

$(\mathrm{CI}=10)$ e índice de condición con un incremento significativo con el tamaño $(\mathrm{CI}=10 \mathrm{xDW}+10)$

The results of these simulations are presented in Fig. 6 , and they highlight an effect of the condition index on the constant in all cases, whereas the exponent is affected only when the condition index increases with weight.

In summary, several studies have demonstrated the influence of endogenous and exogenous factors on the CR allometric relationships. Besides, the present study highlights the influence of the endogenous factor condition index on the CR and weight relationship of Mytilus galloprovincialis. Therefore, the evaluation of clearance rate measurement methodologies cannot be based solely on the allometric relationships of the clearance rate, which are constrained to the particular experimental conditions.

\section{Acknowledgments}

We thank L. Nieto, B. González and R. Salgueiro for technical assistance in the laboratory. Helpful comments by two anonymous reviewers are also acknowledged. This study was supported by the contract-project PROINSA, Code CSIC 2004448, Xunta de Galicia PGDIT03RMA13E”, and 'UE MABENE EVK3-2001-00144'. R. Filgueira was supported by a research personnel training grant from CSICXunta de Galicia and Caixanova.

\section{Literature cited}

Atanasov AT \& DB Dimitrov. 2002. Changes of the power coefficient in the 'metabolism-mass' relationship in the evolutionary process of animals. BioSystems 66: 65-71. 
Bayne BL. 1998. The physiology of suspension feeding by bivalve molluscs: an introduction to the Plymouth 'TROPHEE' workshop. Journal of Experimental Marine Biology and Ecology 219: 1-19.

Bayne BL, JIP Iglesias, AJS Hawkins, E Navarro, M Heral \& JM Deslous-Paoli. 1993. Feeding behaviour of the mussel, Mytilus edulis: responses to variations in quantity and organic content of the seston. Journal of the Marine Biological Association of the United Kingdom 73: 813829.

Bayne BL \& RC Newell. 1983. Physiological energetics of marine molluscs. In: Wilbur KM (ed), The Mollusca Vol. 4. Physiology. Part 1, pp. 407-515. Academic Press, New York.

Bayne BL, RJ Thompson \& J Widdows. 1976. Physiology: I. In: Bayne BL (ed), Marine mussels: their ecology and physiology, pp. 121-206. Cambridge University Press, London.

Bernard FR. 1983. Physiology and mariculture of some northeastern Pacific bivalve molluscs. Canadian Special Publication of Fisheries and Aquatic Sciences 63: 1-24.

Bokma F. 2004. Evidence against universal metabolic allometry. Functional Ecology 18: 184-187.

Brown JH, VK Gupta, BL Li, BT Milne, C Restrepo \& GB West. 2002. The fractal nature of nature: power laws, ecological complexity and biodiversity. Philosophical Transactions of the Royal Society of London Part B 357: 619-626.

Dodds PS, DH Rothman \& JS Weitz. 2001. Re-examination of the '3/4-law' of Metabolism. Journal of Theoretical Biology 209: 9-27.

Filgueira R, U Labarta \& MJ Fernández-Reiriz. 2006. Flowthrough chamber method for clearance rate measurements in bivalves. Design and validation of individual chambers and mesocosm. Limnology and Oceanography Methods 4: 284-292.

Freeman KR. 1974. Growth, mortality and seasonal cycle of Mytilus edulis in two Nova Scotian embayments. Departament of the Environment, Fisheries and Marine Service, Canada, Technical Report N 500: 1-112.

Hawkins AJS, RFM Smith, BL Bayne \& M Héral. 1996. Novel observations underlying the fast growth of suspension-feeding shellfish in turbid environments: Mytilus edulis. Marine Ecology Progress Series 131: 179190.

Hochachka PW, CA Darveau, RD Andrews \& RK Suarez. 2003. Allometric cascade: a model for resolving body mass effects on metabolism. Comparative Biochemistry and Physiology Part A 134: 675-691.

Iglesias JIP, A Pérez-Camacho, E Navarro, U Labarta, R Beiras, AJS Hawkins \& J Widdows. 1996. Microgeographic variability in feeding, absorption, and condition of mussels (Mytilus galloprovincialis LMK): A transplant experiment. Journal of Shellfish Research 15(3): 673-680.

Jeffrey SW \& NA Welschmeyer. 1997. Spectrophotometric and fluorometric equations in common use in oceanography. In: Jeffrey SW, RFC Montura \& SW Wright (eds), Phytoplankton pigments in oceanography, pp. 597-615. UNESCO, Paris.

Jones HD, OG Richards \& TA Southern. 1992. Gill dimensions, water pumping rate and body size in the mussel Mytilus edulis L. Journal of Experimental Marine Biology and Ecology 155: 213-237.

Jørgensen CB. 1996. Bivalve filter feeding revisited. Marine Ecology Progress Series 142: 287-302.

Jørgensen CB, PS Larsen, F Møhlenberg \& HU Riisgård. 1988. The mussel pump: properties and modelling. Marine Ecology Progress Series 45: 205-216.

Kiørboe T \& F Møhlenberg. 1981. Particle selection in suspension-feeding bivalves. Marine Ecology Progress Series 5: 291-296.

Labarta U, MJ Fernández-Reiriz \& JMF Babarro. 1997. Differences in physiological energetics between intertidal and raft cultivated mussels Mytilus galloprovincialis. Marine Ecology Progress Series 152: 167-173.

Meyhöfer E. 1985. Comparative pumping rates in suspensionfeeding bivalves. Marine Biology 85: 137-142.

Møhlenberg F \& HU Riisgård. 1979. Filtration rate, using a new indirect technique, in thirteen species of suspensionfeeding bivalves. Marine Biology 54: 143-147.

Morton B. 1983. Feeding and digestion in Bivalvia. In: Wilbur KM (ed), The Mollusca Vol. 5, Physiology, Part 2, pp. 65147. Academic Press, New York.

Muller-Landau HC, RS Condit, J Chave, SC Thomas, SA Bohlman, S Bunyavejchewin, S Davies, R Foster, S Gunatilleke, KE Harms, T Hart, SP Hubbell, A Itoh, AR Kassim, JV LaFrankie, HS Lee, E Losos, JR Makana, T Ohkubo, R Sukumar, IF Sun, N Supardi, S Tan, J Thompson, R Valencia, GV Muñoz, C Wills, T Yamakura, G Chuyong, HS Dattaraja, S Esufali, P Hall, C Hernandez, D Kenfack, S Kiratiprayoon, HS Suresh, D Thomas, MI Vallejo \& P Ashton. 2006. Testing metabolic ecology theory for allometric scaling of tree size, growth and mortality in tropical forests. Ecology Letters 9: 575-588.

Pérez-Camacho A \& R González. 1984. La filtración del mejillón (Mytilus edulis L.) en laboratorio, Actas do Primeiro Semminario de Ciencias do Mar as Rías Galegas. Cuadernos de Area de Ciencias Marinas. Seminario de Estudos Galegos 1: 427-437.

Powell EN, EE Hofmann, JM Klinck \& SM Ray. 1992. Modeling oyster populations. I. A commentary on filtration rate. Is faster always better? Journal of Shellfish Research 11(2): 367-398. 
Reich PB, MG Tjoelker, JL Machado \& J Oleksyn. 2006. Universal scaling of respiratory metabolism, size and nitrogen in plants. Nature 439: 457-461.

Riisgård HU \& F Møhlenberg. 1979. An improved automatic recording apparatus for determining the filtration rate of Mytilus edulis as a function of size and algal concentration. Marine Biology 52: 61-67.

Riisgård HU. 1988. Efficiency of particle retention and filtration rate in 6 species of Northeast American bivalves. Marine Ecology Progress Series 45: 217-223.

Riisgård HU. 1998. No foundation of a ' $3 / 4$ power scaling law’ for respiration in biology. Ecology Letters 1: 71-73.

Riisgård HU. 2001a. Physiological regulation versus autonomous filtration in filter-feeding bivalves: starting points for progress. Ophelia 54(3): 193-209.

Riisgård HU. 2001b. On measurement of filtration rates in bivalves - the stony read to reliable data: review and interpretation. Marine Ecology Progress Series 211: 275291.

Snedecor GW \& GW Cochran. 1989. Statistical Methods, 503 pp. Iowa State University Press, Ames.
Sprung M. 1995. Physiological energetics of the zebra mussel Dreissena polymorpha in lakes II. Food uptake and gross growth efficiency. Hydrobiologia 304: 133-146.

Vahl O. 1973. Pumping and oxygen consumption rates of Mytilus edulis L. of different sizes. Ophelia 12: 45-52.

West GB, JH Brown \& BJ Enquist. 1997. A general model for the origin of allometric scaling laws in biology. Science 276: $122-126$.

West GB, JH Brown \& BJ Enquist. 1999. The fourth dimension of life: fractal geometry and allometric scaling of organisms. Science 284: 1677-1679.

White CR, NF Phillips \& RS Seymour. 2006. The scaling and temperature of vertebrate metabolism. Biology Letters 2: $125-127$.

White CR \& RS Seymour. 2003. Mammalian basal metabolic rate is proportional to body mass ${ }^{2 / 3}$. Proceedings of the National Academy of Sciences USA 100: 4046-4049.

Winter JE. 1976. A critical review on some aspects of filterfeeding in lamellibranchiate bivalves. Haliotis 7: 71-87.

Zar JH. 1984. Biostatistical analysis, 718 pp. Prentice-Hall, Englewood Cliffs.

Recibido el 5 de mayo de 2008 y aceptado el 23 de junio de 2008 